\title{
Basic responses of mesenchymal stem cells exposed to bovine biomaterial and platelet rich fibrin
}

Respostas básicas de células-tronco mesenquimais expostas ao biomaterial bovino e em fibrina rica em plaquetas

Respuestas básicas de las células madres mesenquimales expuestas a biomaterial bovino y fibrina rica en plaquetas

Janaína Lima Heymovski ORCID: https://orcid.org/0000-0002-0586-0814 Universidade Positivo, Brazil

E-mail: janaheymovski@gmail.com

Moira Pedroso Leão

ORCID: https://orcid.org/0000-0003-3724-911X Curityba Biotech, Brazil

E-mail: moirapedroso@gmail.com

Jeferson Luis de Oliveira Stroparo ORCID: https://orcid.org/0000-0003-1094-530X Universidade Positivo, Brazil

E-mail: jef_stroparo@hotmail.com

Sabrina Cunha da Fonseca

ORCID: https://orcid.org/0000-0001-5280-1238

Universidade Federal do Paraná, Brazil

E-mail: sabrina.cfonseca@hotmail.com

Lisley Janowski Spisila

ORCID: https://orcid.org/0000-0002-3978-3650 Universidade Federal do Paraná. Brazil

E-mail: lisleyjspisila@gmail.com

Carla Castiglia Gonzaga

ORCID: https://orcid.org/0000-0001-6374-1605 Universidade Positivo, Brazil

E-mail: carlacgonzaga2@gmail.com

Victoria Cruz Cavalari

ORCID: https://orcid.org/0000-0002-0232-7328 Curityba Biotech, Brazil

E-mail: vitoria_cavalari@hotmail.com

Rafaela Araújo Mendes

ORCID: https://orcid.org/0000-0002-3774-6354 Universidade Positivo, Brazil

E-mail: rafaela.mendes@live.com

Denis Roberto Falcão Spina

ORCID: https://orcid.org/0000-0002-3040-9515 Instituto Federal de Educação Ciência e Tecnologia do Paraná, Brazil E-mail: drfspina@gmail.com

Eduardo Discher Vieira

ORCID: https://orcid.org/0000-0002-4311-1486 Curityba Biotech, Brazil

E-mail: eduardo.discher@outlook.com

Roberto da Rocha Leão Neto

ORCID: https://orcid.org/0000-0002-1379-7819 Universidade Positivo, Brazil E-mail: leaorep@gmail.om

Leonel Alves de Oliveira

ORCID: https://orcid.org/0000-0003-2235-4443 University of Brasilia, Brazil

E-mail: profleone12@gmail.com

Célia Regina Cavichiolo Franco ORCID: https://orcid.org/0000-0003-2525-7788

Universidade Federal do Paraná, Brazil E-mail: crcfranc@terra.com.br 


\author{
Tatiana Miranda Deliberador \\ ORCID: https://orcid.org/0000-0003-4076-4905 \\ Instituto Latino Americano de Pesquisa e Ensino Odontológico, Brazil \\ E-mail: tdeliberador@gmail.com \\ João César Zielak \\ ORCID: https://orcid.org/0000-0003-3393-3491 \\ Universidade Positivo, Brazil \\ E-mail: jzielak2@gmail.com
}

\begin{abstract}
Scaffolds and their interaction with mesenchymal stem cells are objects of study in bioengineering and tissue repair. Mechanisms such as proliferation, viability, and cytotoxicity are essential for the development of therapies. The present study analyzed the influence of platelet-rich fibrin (PRF) in viability, cytotoxicity, and proliferation of stem cells from human exfoliated deciduous teeth (SHED) exposed to bovine biomaterial surfaces. The studied groups were divided and analyzed as follows: (S) only SHED as control Group; (SB) SHED + biomaterial; (SBP) SHED + biomaterial + PRF. Analyses of cells seeded in 24-well plates were performed after 24, 48 and 72 hours. Individual groups were subjected to viability, cytotoxicity and cell proliferation tests using neutral red, MTT and crystal violet, respectively; and in the 72-hour group, scanning electron microscopy (SEM) was performed to record cell ultramorphology. Data were submitted to statistical analysis by two-factor ANOVA with a significance level of 5\%. The results demonstrated a better performance in the viability/cytotoxicity and proliferation of stem cells for the group (SBP) in comparison to the group (SB) and the group (S). The applied statistical tests showed that the biomaterial factor, time, and interaction between them led to results with statistical significance. SHED submitted to bovine biomaterial were more viable, proliferative and with lower citotoxicity when associated with PRF. PRF seemed to activate the metabolism of stem cells in culture, indicating that such an association can bring an effective benefit in clinical outcome.
\end{abstract}

Keywords: Mesenchymal stem cells; Biomaterial; Platelet-rich-fibrin; Bone regeneration; Cell proliferation; Regenerative medicine.

\title{
Resumo
}

Arcabouços e a suas interações com as células-tronco mesenquimais são objetos de estudo em bioengenharia e reparo de tecidos. Mecanismos como proliferação, viabilidade e citotoxicidade são fundamentais para o desenvolvimento de terapias. $\mathrm{O}$ presente estudo analisou a influência da fibrina rica em plaquetas (PRF) na viabilidade, citotoxicidade e proliferação de células-tronco mesenquimais de dentes decíduos humanos esfoliados (SHED) em contato com biomaterial de origem bovina. Os grupos estudados foram divididos e analisados da seguinte forma: (S) apenas SHED como Grupo controle; (SB) SHED + biomaterial; (SBP) SHED + biomaterial + PRF. As análises das células semeadas em placas de 24 poços foram realizadas após 24, 48 e 72 horas. Grupos individuais foram submetidos a testes de viabilidade, citotoxicidade e proliferação celular usando vermelho neutro, MTT e cristal violeta, respectivamente, e no grupo de 72 horas foi realizada a microscopia eletrônica de varredura (MEV) para registrar a ultra morfologia celular. Os dados foram submetidos à análise estatística por ANOVA de dois fatores com nível de significância de 5\%. Os resultados demonstraram um melhor desempenho na viabilidade / citotoxicidade e proliferação de células-tronco para o grupo (SBP) em relação ao grupo (SB) e ao grupo (S). Os testes estatísticos aplicados mostraram que o fator biomaterial, o tempo e a interação entre eles deram origem a resultados com significância estatística. As SHED submetidas ao biomaterial bovino se apresentaram mais viáveis, proliferativas e com menor citotoxicidade quando associadas à PRF. A PRF pareceu ativar o metabolismo das células-tronco em cultivo, indicando que tal associação pode trazer um benefício efetivo nos desfechos clínicos.

Palavras-chave: Células-tronco mesenquimais; Biomaterial; Fibrina rica em plaquetas; Regeneração óssea; Proliferação celular; Medicina regenerativa.

\section{Resumen}

Marcos y tus interacciónes con las células madres mesenquimales son objetos de estudio en bioingeniería y reparación de tejidos. Mecanismos como la proliferación, la viabilidad y la citotoxicidad son fundamentales para el desarrollo de terapias. El presente estudio analizó la influencia de la fibrina rica en plaquetas (PRF) sobre la viabilidad, citotoxicidad y proliferación de células madre mesenquimales de dientes primarios humanos exfoliados (SHED) en contacto con biomateriales bovinos. Los grupos estudiados se dividieron y analizaron de la siguiente manera: (S) solo SHED como grupo de control; (SB) SHED + biomaterial; (SBP) SHED + biomaterial + PRF. Se realizaron análisis de células sembradas en placas de 24 pocillos después de 24, 48 y 72 horas. Los grupos individuales se sometieron a pruebas de viabilidad, citotoxicidad y proliferación celular utilizando rojo neutro, MTT y violeta cristal, respectivamente, y en el grupo de 72 horas, se realizó microscopía electrónica de barrido (SEM) para registrar la morfología celular. Los datos se sometieron a análisis estadístico mediante ANOVA de dos factores con un nivel de significancia del 5\%. Los resultados demostraron un mejor desempeño en la viabilidad / citotoxicidad y proliferación de células madre para el grupo (SBP) en comparación con el grupo (SB) y el grupo (S). Las pruebas estadísticas 
aplicadas mostraron que el factor biomaterial, el tiempo y la interacción entre ellos dieron lugar a resultados con significación estadística, las SHED sometidas a biomaterial bovino fueron más viables, proliferativos y con menor toxicidad cuando se asociaron con PRF. PRF parecio activar el metabolismo de las células madres en cultivo, lo que indica que tal asociación puede aportar un beneficio efectivo en los resultados clínicos.

Palabras clave: Células madres mesenquimal; Biomaterial; Fibrina rica en plaquetas; Regeneración ósea;

Proliferación celular; Medicina regenerativa.

\section{Introduction}

Tissue engineering is the use of a combination of multidisciplinary approaches with the aim to improve or replace biological tissues (Huawei et al. 2019) and it is highly applied in reconstructive surgery procedures such as bone augmentation. The essential elements needed are osteoconductive scaffolds, osseoinductive growth factors and progenitor cells.

Autologous mesenchymal stem cells from the adjacent tissues to the bone, such as periosteum and bone marrow, represent the first source of undifferentiated cells for bone reconstruction. However, mesenchymal stem cells can be obtained from other sources, such as adipose, stromal fraction of bone, dental pulp tissues (Strauer et al., 2008) and stem cells from human exfoliated deciduous teeth (SHED) (Miura et al., 2003), for use in regenerative medicine for bone tissue repair. Nevertheless, SHED represent a viable source for mesenchymal stem cells obtained, once the young human being has twenty opportunities for collection, because of the deciduous teeth natural process of exfoliation. Another important element to be considered is cell interaction with osseocondutor mineralized biomaterials when acting the basic components of scaffolds and play a fundamental role in bone tissue engineering (Huawei et al., 2019). Xenogenic sources, such as bovine, are extensively (Precheur, 2007) due to their ultrastructural characteristics, which can drive the development of new bone tissue. In addition to that, osteoconductive materials are biocompatible of a bone neoformed structure (Moraschini et al., 2015).

Finally, the mesenchymal stem cells need signalizing specific growth factors and cytokines signaling to promote transduction, gene transcription and protein synthesis, modulating chemotaxis, migration, proliferation, and cell differentiation.

The autologous platelet-rich fibrin (PRF) is an additional scaffold and can act as a continuum medium between cells and the biomaterial surface. The PRF possesses supraphysiologicalgrowth factors concentrations, glycoproteins with adhesives properties, and contains live and functional platelets and leukocytes and a variety of cell compounds like immunoglobulins and ligand molecules (Miron et al., 2017; Oliveira et al., 2020). Based on these properties, the PRF can promote induction proliferation and differentiation of osteoprogenitor cells and improve bone regeneration in reconstruction surgeries (He et al., 2009; Dohan et al., 2009).

Thus, the present study aims to qualitatively evaluate the influence of PRF in the levels of cytotoxicity, viability, and proliferation status of mesenchymal stem cells associated with a bovine bone grafting biomaterial.

\section{Methodology}

\subsection{Individuals and ethical aspects}

The present study observed all ethical standards for scientific research with humans in conformity with the Declaration of Helsinki (World Medical Association Recommendation 2013). The mesenchymal stem cells were obtained from a twelveyear-old donor after the signed an informed consent form. A healthy tooth, without caries, with complete rhizolysis, was used at the time of natural tooth exfoliation. The blood donation (single donor, thirty-year-old) for PRF preparation followed the same ethical steps. The Research Ethics Committee of Universidade Positivo approved the study under number 
3.6665.172/2019. The methodology herein presented followed de Oliveira et al. (2020), Lisboa et al. (2021) and Stroparo et al. (2021).

\subsection{Stem Cell Culture}

After oral prophylaxis, the exfoliated tooth was inserted in a container with sterile medium (DMEM [Dulbecco's Modified Eagle's Medium] $+10 \%$ Fetal Bovine Serum $+1 \%$ streptomycin/penicillin $+1 \%$ amphotericin). Explant cells process and primary culture was obtained.

All cells were kept in a $\mathrm{CO}_{2}$ incubator at $37^{\circ} \mathrm{C}$ with the same medium. The cells were cultivated until they reached $80 \%$ confluence at the $4^{\text {th }}$ passage, observed in the inverted microscope. Trypsin was used and $4 \times 10^{4}$ cells were seeded in three wells (24-well plate) for each group, at 24, 48 and 72 hours. Mesenchymal stem cells were characterized by Dominici protocols (2006). This methodology was describeb by Lisboa et al. (2021) and Stroparo et al. (2021).

\subsection{Obtaining the PRF matrices by centrifugation}

A healthy and non-smoker adult voluntarily donated a total of $80 \mathrm{ml}$ of blood, collected in 9,0 ml sterile polystyrene vacuum tubes (Greiner Bio-One, Brazil) for PRF production. Blood samples immediately transferred to fixed-angle centrifuge FibrinFuge25 (Montserrat, Brazil), centrifuged with $200 \times$ g for 10 minutes, in conformity with de Oliveira et al. (2020). The methodology can be seen in Figure 1.

\subsection{Experimental groups}

Cells from culture flasks were washed with $\mathrm{PBS}$ at $37^{\circ} \mathrm{C}$, treated with trypsin and resuspended with $1 \mathrm{ml}$ of culture medium; a small aliquot was counted in Neubauer chamber and $4 \times 10^{4}$ cells that were plated in the experiment wells. In vitro tests were performed on 24-well plates (Greiner, Germany), in doble triplicates. The groups were divides as follows.

1) Group C (Control, SHED only): in the wells of the control group, the SHED was seeded and maintained only in supplemented DMEM.

2) Group B (SHED + Biomaterial): wells containing SHED received a $33.6 \mathrm{~mm}^{2}$ transwell insert, with pores of $3 \mu \mathrm{m}$ in diameter (Easy Strainer, Greiner Bio-One, Kremsmünster, Austria), with an amount of $0.03 \mathrm{~g}$ of biomaterial (Lumina Bone®, Critéria, São Carlos, SP, Brazil). The inserts were put into the wells and were submerged in the DMEM culture medium.

3) Group BP (SHED + Biomaterial + PRF): wells containing SHED received the transwell insert, with the amount of $0.03 \mathrm{~g}$ of biomaterial (Lumina Bone®, Critéria, São Carlos, SP, Brazil) associated with a fragment of PRF (0.03 ml). The inserts were put into the wells and were submerged in the DMEM culture medium. 
Figure 1 - Methodology and division in groups.

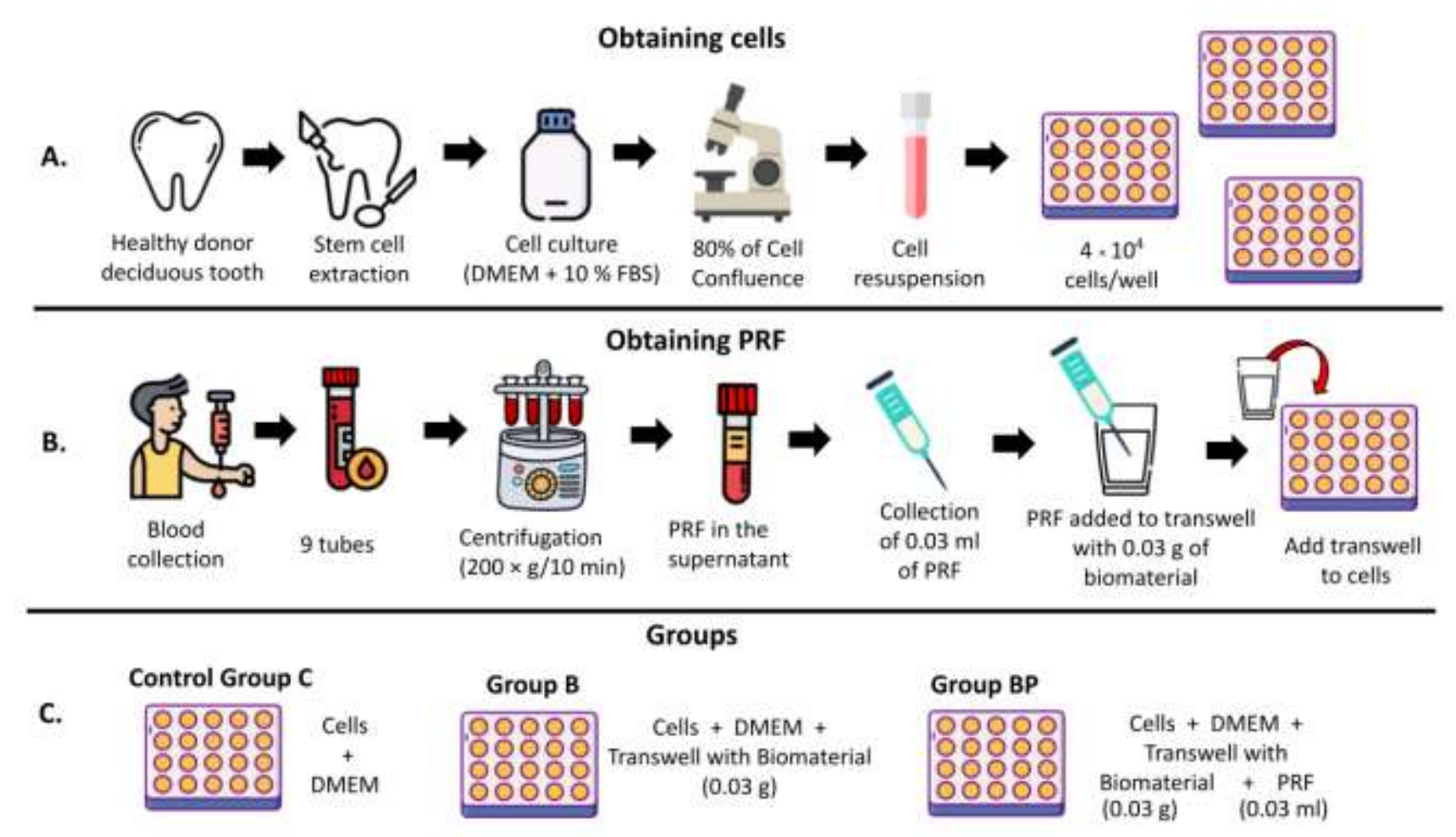

Methodology used for the acquisition of stem cells from deciduous tooth (A); and acquisition of platelet-rich fibrin (PRF) (B); division of experimental groups $(\mathrm{C})$. Group C $=$ Control (SHED only). Group B $=$ SHED + Biomaterial. Group BP $=$ SHED + Biomaterial + PRF Source: Authors; image icons made by Freepik; Monkik, Smalllikeart, Eucalyp; Flat Icons; photo3idea-studio from www.flaticon.com.

\subsection{Cell Viability - Neutral Red}

The Neutral Red method was performed according to the methodologies described by Borenfreund and Puerner (1985), Chaim et al. (2006) and Fotakis and Timbrell (2006). At 24, 48 and 72 hours of culture, the cells were incubated with $37.5 \mu \mathrm{l}$ of a neutral red stock solution (1100 $\mu \mathrm{g} / \mathrm{ml}$, Sigma-Aldrich / Merck, Darmstadt, Germany) diluted in PBS, and then diluted in $337.5 \mu \mathrm{l}$ of the culture medium, thus obtaining a final concentration of $100 \mu \mathrm{g} / \mathrm{ml}$ of neutral red. The absorbance was read in a microplate reader $(540 \mathrm{~nm}$, Biotek, Winooski, USA).

\subsection{Cellular Cytotoxicity - MTT}

The MTT method was performed according to the methodology described by Mosmann (1983), Reilly et al. (1998), and Fotakis and Timbrell (2006). At 24, 48 and 72 hours of culture, the cells were incubated with $37.5 \mu 1$ of a $5 \mathrm{mg} / \mathrm{ml}$ MTT stock solution (Thiazolyl Blue Tetrazolium Bromide, Sigma-Aldrich / Merck, Darmstadt, Germany), in $337.5 \mu 1$ of culture medium.

The Formazan crystals were dissolved in $200 \mu \mathrm{l}$ of DMSO, then the contents of the wells were removed, and the absorbance was read in a microplate reader (BIOTEK, Winooski, USA) at a wavelength of $570 \mathrm{~nm}$.

\subsection{Cell proliferation - Crystal Violet Assay}

After the period of 24, 48 and 72 hours of culture, the cells were fixed with $2 \%$ paraformaldehyde for 30 minutes, washed 2 times with PBS, stained with $300 \mu$ of the $0.2 \%$ violet crystal solution in $5 \%$ ethanol, for 5 minutes, and then washed $10 \times$ with PBS. The dye was then eluted with $200 \mu 1$ of the 33\% acetic acid solution in ultrapure water (15 minutes), according to Gillies et al. (1986). 
The absorbance reading was performed in a microplate reader (BIOTEK, Winooski, USA) at a wavelength of $570 \mathrm{~nm}$.

\subsection{Scanning Electron Microscopy Analysis}

The PRF clot fragments obtained by $200 \times \mathrm{g} / 10$ minutes were separated and conditioned in plastic tubes that were free of additives (Greiner Bio-One, Brazil). Immediately after PRF production and after 24,48 and $72 \mathrm{~h}$ at $37^{\circ} \mathrm{C}$, the specimens were sectioned (body, buffy coat 3 of 12 proximal sediment) and fixed in $2 \%$ glutaraldehyde solution and $2 \%$ paraformaldehyde in $0.1 \mathrm{M}$ sodium cacodylate buffer, $\mathrm{pH}$ 7.2. After being fixed, they were washed in $0.1 \mathrm{M}$ sodium cacodylate buffer, post-fixed in osmium tetroxide (1\%) in sodium cacodylate buffer, then the specimens were dehydrated for 15 minutes in solutions with increasing concentrations of acetone (30\%, 50\%, 70\%, 90\% and 3x 100\%). Afterwards, the specimens were dried to the critical point with $\mathrm{CO}_{2}$ and metalized with gold. For analyzes by scanning electron microscopy (Vega3 - Tescan Orsay Holding, Kohoutovice, Czech Republic), the images (20 to $20000 \times$ of magnification) were analyzed by using GIMP 2.10 software (Cockroach Labs, USA). For the morphometric study the diameter of twenty fibers was evaluated using the digital planimeter of Autocad software (Autodesk, USA).

\subsection{Statistical analysis}

The data used for the different tests of cell viability, cytotoxicity and cell proliferation were analyzed statistically by two-way ANOVA and Tukey's test with a significance level of 5\%.

\section{Results}

\subsection{Cell Viability - Neutral Red}

Despite being non-toxic, in $24 \mathrm{~h}$ the Group B samples showed a lower viability than the control, with results between 38 to $58 \%$; while in the Group BP the viability was close to $60 \%$. In $48 \mathrm{~h}$, the experimental groups showed an improvement in viability in relation to the $24 \mathrm{~h}$ test, with viability between 40 to $70 \%$ in Group B, and viability greater than 60\% in Group BP. The results within $72 \mathrm{~h}$ showed even more improvement in comparison to 24 and $48 \mathrm{~h}$, while Group (B) showed viability greater than 50\%, the Group BP presented viability greater than 70\%, with results surprisingly higher than the control. The results are shown in Figure 2 (1A, 1B, 1C).

The means and standard deviations for the groups that were evaluated indicated statistically significant differences for the biomaterial factor $(\mathrm{p}=0.001)$ and time $(\mathrm{p}<0.001)$. The double interaction was statistically significant $(\mathrm{p}=0.037)$, as shown in Table 1.

Table 1 - Means \pm standard deviations for cell viability values using the Neutral Red method for different groups and times.

\begin{tabular}{l|l|l|l}
\hline \multirow{2}{*}{ Group } & \multicolumn{2}{|l}{ Time $(\mathrm{h})$} & \multicolumn{2}{l}{} \\
\cline { 2 - 4 } & 24 & 48 & \multicolumn{2}{l}{} \\
\hline $\mathrm{C}$ & $0.6768 \pm 0.1527 \mathrm{Aa}$ & $0.6855 \pm 0.1277 \mathrm{Aa}$ & $0.6893 \pm 0.0394 \mathrm{Aab}$ \\
\hline $\mathrm{B}$ & $0.4688 \pm 0,0655 \mathrm{Ab}$ & $0,5310 \pm 0.0708 \mathrm{ABab}$ & $0.6190 \pm 0.0587 \mathrm{Ab}$ \\
\hline BP & $0.5237 \pm 0.0864 \mathrm{Bab}$ & $0.6267 \pm 0.0891 \mathrm{Bb}$ & $0.7772 \pm 0.0489 \mathrm{Aab}$ \\
\hline
\end{tabular}

Group C = Control (SHED only). Group B = SHED + Biomaterial. Group BP = SHED + Biomaterial + PRF. In the line, values followed by the same capital letters are statistically similar ( $>>0.05$ ). In the column, values followed by the same lower case letters are statistically similar $(p>0.05)$. The higher the number, the better the cell viability achieved. Source: Authors. 


\subsection{Cell Cytotoxicity - MTT}

The MTT results for $24 \mathrm{~h}$ indicate no toxicity, in which the Group B had 100\% viable cells; however, the Group BP showed a small decrease at this MTT assay. In 48 hours, none of the groups presented toxicity, with $100 \%$ viable cells; a similar result was observed in the 72-hour period. The results are shown in Figure 2 (2A, 2B, 2C).

Therefore, the results indicated statistically significant differences for the biomaterial factor $(p=0.032)$ and time $(p$ $<0.001)$. The double interaction was not statistically significant $(\mathrm{p}=0.480)$, as shown in Table 2 .

Table 2 - Means and standard deviations for cell cytotoxicity values using the MTT method for different biomaterials and times.

\begin{tabular}{l|l|l|l|l}
\hline \multirow{2}{*}{ Group } & \multicolumn{2}{l|}{ Time $(\mathrm{h})$} & 72 & Total \\
\cline { 2 - 5 } & 24 & 48 & $0.2600 \pm 0.0059$ & $0.2074 \pm 0.0498 \mathrm{~A}$ \\
\hline $\mathrm{C}$ & $0.1483 \pm 0.0142$ & $0.2138 \pm 0.0252$ & $0.2702 \pm 0.1086$ & $0.2061 \pm 0.0768 \mathrm{~A}$ \\
\hline $\mathrm{B}$ & $0.1592 \pm 0,0172$ & $0.1888 \pm 0.0047$ & $0.2162 \pm 0.0160$ & $0.1763 \pm 0.0333 \mathrm{~B}$ \\
\hline BP & $0.1420 \pm 0.0084$ & $0.1708 \pm 0.0098$ & $0.2448 \pm 0.0643 \mathrm{a}$ & \\
\hline Total & $0.1498 \pm 0,0148 \mathrm{c}$ & $0.1912 \pm 0.0235 \mathrm{~b}$ & & \\
\hline
\end{tabular}

Group C = Control (SHED only). Group B = SHED + Biomaterial. Group BP = SHED + Biomaterial + PRF. In the line, values followed by the same capital letters are statistically similar ( $p>0.05$ ). In the column, values followed by the same lower case letters are statistically similar ( $p>0.05$ ). Source: Authors.

\subsection{Cell proliferation - Crystal Violet Assay}

It can be seen in $24 \mathrm{~h}$ that Group B has an anti-proliferative effect with a decrease in cell density. However, a slight stimulus was observed in the Group BP. In 48h, Group B had a more pronounced anti-proliferative effect in comparison to the same group in 24h. Meanwhile, the Group BP showed a greater stimulus in proliferation, like that of the control. Finally, at 72 h, the Group B had a greater anti-proliferative effect in comparison to the 24 and $48 \mathrm{~h}$. Notably, the Group BP had a pronounced proliferation stimulating effect, with results greater than the control. The results are shown in Figure 2 (3A, 3B, $3 \mathrm{C})$.

The results indicated statistically significant differences for the biomaterial factor $(\mathrm{p}=0.001)$ and time $(\mathrm{p}<0.001)$. Double interaction was not statistically significant $(\mathrm{p}=0.001)$, as shown in Table 3.

Table 3 - Means and standard deviations for cell proliferation values using the violet crystal method for different biomaterials and times.

\begin{tabular}{l|l|l|l}
\hline \multirow{2}{*}{ Group } & \multicolumn{2}{|l}{ Time (h) } \\
\cline { 2 - 4 } & 24 & 48 & 72 \\
\hline C & $0.3977 \pm 0.0837 \mathrm{Ba}$ & $1.0582 \pm 0.1679 \mathrm{Aa}$ & $1.0572 \pm 0.1428 \mathrm{Ab}$ \\
\hline $\mathrm{B}$ & $0.2795 \pm 0.0405 \mathrm{Ba}$ & $0.6350 \pm 0.1540 \mathrm{Ab}$ & $0.5827 \pm 0.1510 \mathrm{Ac}$ \\
\hline $\mathrm{BP}$ & $0.3265 \pm 0.0328 \mathrm{Ca}$ & $0.9637 \pm 0.1408 \mathrm{Ba}$ & $1.2742 \pm 0.1286 \mathrm{Aa}$ \\
\hline
\end{tabular}

Group C = Control (SHED only). Group B = SHED + Biomaterial. Group BP = SHED + Biomaterial + PRF. In the line, values followed by the same capital letters are statistically similar ( $p>0.05)$. In the column, values followed by the same lowercase letters are statistically similar $(p>0.05)$ The higher the number, the more cell proliferation was observed. Source: Authors. 
Figure 2 - Results of cell viability, cell cytotoxicity and cell proliferation tests for different groups and times.
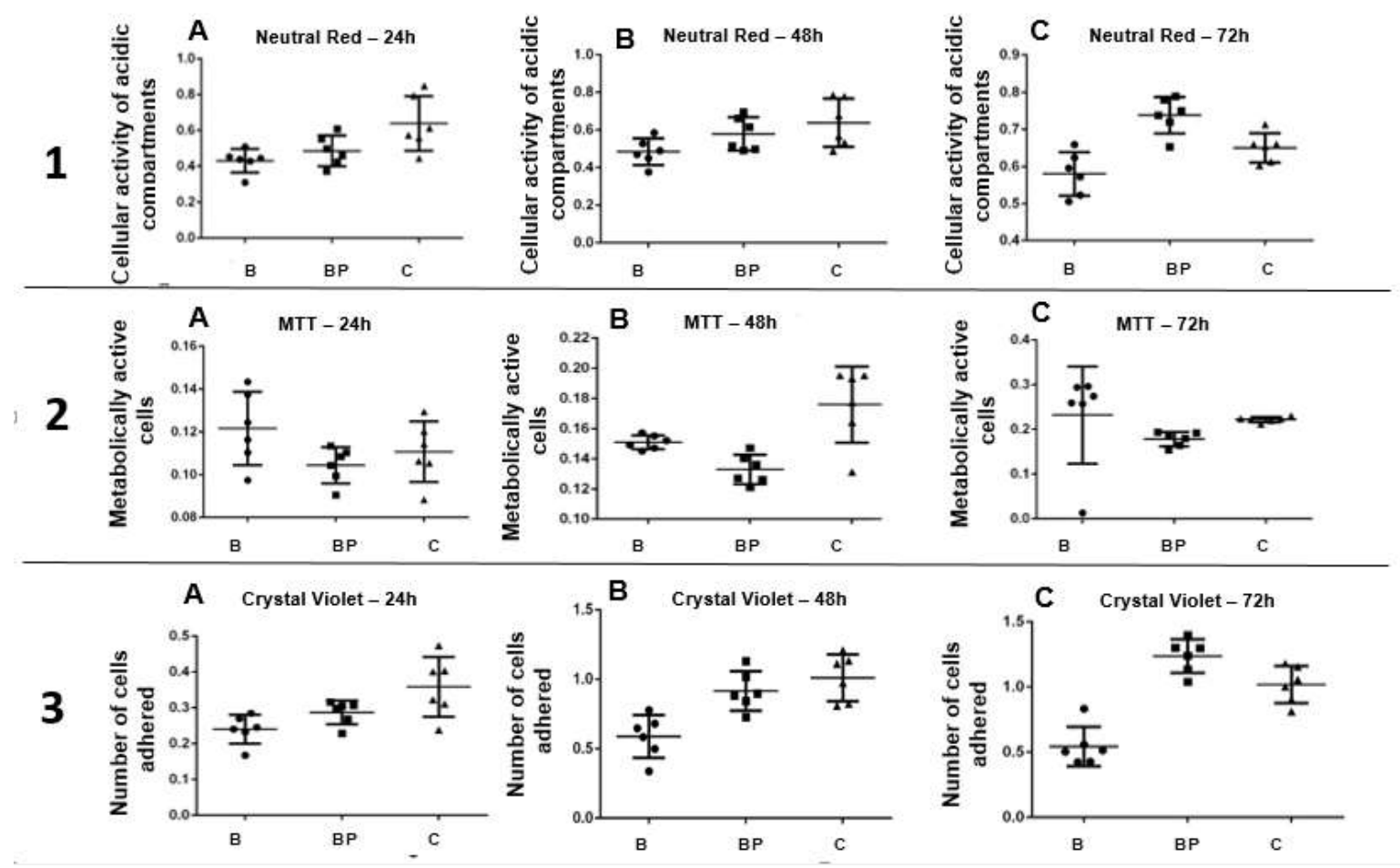

(Letters on the $\mathrm{x}$ coordinate in the graphics) $\mathrm{B}=$ Group $\mathrm{B}=\mathrm{SHED}+$ Biomaterial. $\mathrm{BP}=$ Group BP $=\mathrm{SHED}+\mathrm{Biomaterial}+\mathrm{PRF}$. C $=$ Group $\mathrm{C}=$ Control group (SHED only). Results of the cell viability by Neutral Red test are shown in line 1, in $24 \mathrm{~h}(1 \mathrm{~A}), 48 \mathrm{~h}(1 \mathrm{~B}), 72 \mathrm{~h}(1 \mathrm{C}) ;$ line 2 shows the cell cytotoxicity through MTT test, in $24 \mathrm{~h}(2 \mathrm{~A}), 48 \mathrm{~h}(2 \mathrm{~B})$ and $72 \mathrm{~h}(2 \mathrm{C})$. Line 3 shows the results of cell proliferation by Crystal Violet assay in $24 \mathrm{~h}(3 \mathrm{~A}), 48 \mathrm{~h}(3 \mathrm{~B})$ and $72 \mathrm{~h}(3 \mathrm{C})$. Source: Authors.

\subsection{Scanning Electron Microscopy - SEM}

By SEM, it was possible to verify the adhesion to the surface at the Group BP after $72 \mathrm{~h}$ of treatment, which presents fusiform morphology (Figures 3 and 4). The SEM refers to sparse cells still with a fibroblastic characteristic after 72 hours of culture with stabilization of cell morphology and increased proliferation. 
Research, Society and Development, v. 10, n. 11, e46101119134, 2021

(CC BY 4.0) | ISSN 2525-3409 | DOI: http://dx.doi.org/10.33448/rsd-v10i11.19134

Figure 3 - Group BP $=$ SHED + Biomaterial + PRF .

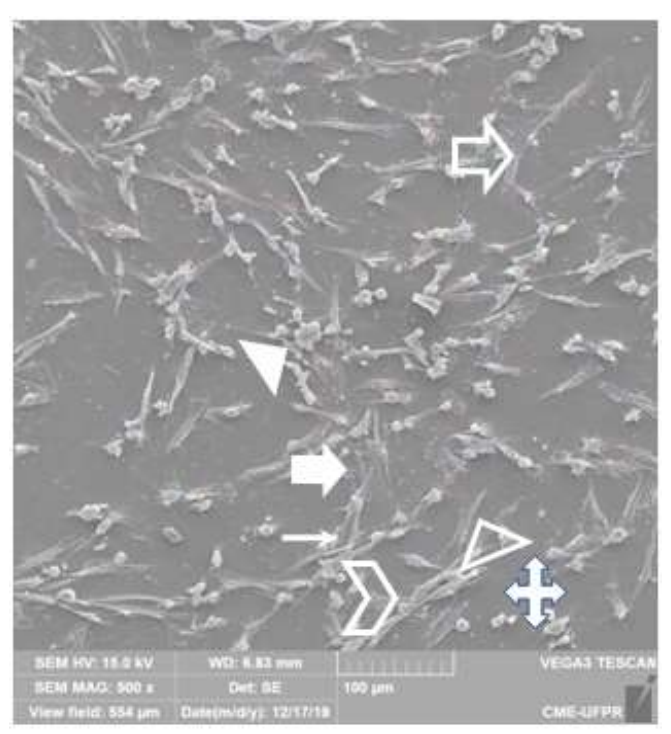

This arrowhead identifies cells adhered and spread to the substrate;

This arrow identifies cells with different morphological patterns;

This arrow identifies contact inhibition;

$\Rightarrow$

This arrowidentifies contactinhibition;

This arrow identifies cells in subconfluence;

This hollow arrowhead identifies cellular projections in the form of filopodia;

This arrow identifies larger cells with more elongated morphology

This arrow identifies a smaller number of cells, smaller cells, less spread out, with a greater number of rounded cells.

Group BP with 72 h. SEM, $500 \times$. Source: Authors. 


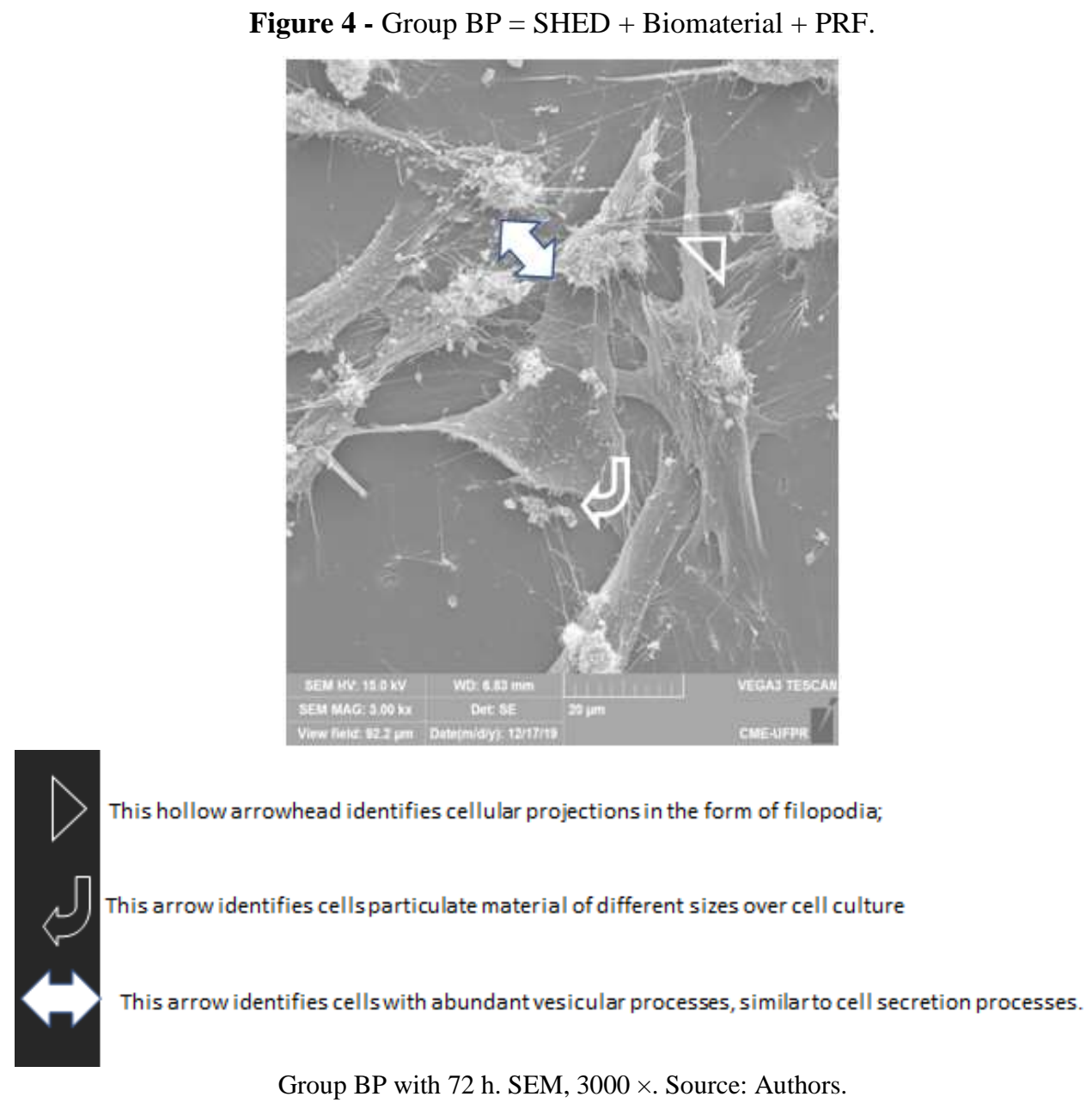

\section{Discussion}

Isolated from sources such as those of primary tooth pulp, human MSC appears as a model closer to the reality found in the clinic for testing new techniques and products, prior to animal tests or clinical trials. As well as stem cells, additional elements have shown valuable properties for application in the clinical and surgical context, such as PRF, which has great biological potential in wound healing (Massuda et al., 2020). Considering these facts, the objective of this study was the analysis of the viability / cytotoxicity and proliferation of human mesenchymal stem cells, obtained from the collection of pulp from the primary tooth in exfoliation, in the presence of bovine biomaterial associated or not with PRF. Dohan et al. (2014) mention an increasing amount of data about the clinical success of PRF use, which corroborates with our results. In the analysis carried out for cell viability (Neutral Red), the group B presented the lower viability within groups. By adding the PRF (Group BP) viability was restored, indicating that PRF might have protective and non-apoptotic actions for MSC.

The standard cytotoxicity MTT assay is important for determining the safety of the analyzed compound. Similarly, to our study, Abuarqoub et al. (2020) used MTT in different concentrations of biomaterial in cultures of MSC from the periodontal ligament. Dahake et al (2019) also used MTT to assess the cytotoxicity of three biomaterials with osteoinductive potential but performed the analysis in just 1 time (7 days) in contact with SHED. In this present work, 24, 48 and 72 hours were chosen to evaluate whether or not there would be a toxic action of the studied biomaterials and if this cytotoxicity could change over the hours. The results presented in this work point to a low toxicity of the bovine biomaterial and PRF for the MSC in the analyzed times. Notably, the BP group showed the lowest cytotoxicity compared to the other groups. 
In the evaluation of proliferation by means of the crystal violet assay, it was observed that after $72 \mathrm{~h}$ that Group B had an anti-proliferative effect; in an opposite way, a stimulating effect of proliferation was found in Group BP, suggesting that the association of SHED + biomaterial + PRF influences SHED to multiply with greater intensity. Studies point to such an association as a strong adjunct in the treatment of various diseases (Orlic et al., 2002; Oliveira et al., 2017).

The SEM images of the SHED were obtained from samples of Group BP, at 72 hours, because in this group and at this time they were more proliferative. Sparse cells, with fusiform aspect and characteristics of stabilization of cell morphology and increased proliferation were observed. These results are in line with different studies, such as those described by Yamada and Watari (2003), Lendeckel et al. (2004), Ratnayake and Currie (2017), as well as in the study proposed by Amaral (2006), who investigated the morphological characteristics of mesenchymal stem cells and their differentiation capacity.

Naz et al. (2019) and Nakajima et al. (2019) emphasize the need for using standardized and adequate protocols for this type of assessments to comply with the necessary requirements for the biocompatibility process (Sanada et al., 2003; Rosa et al., 2000). In this study, the followed methodology has proven to be viable and reproducible for future research, suggesting future studies with longer periods and immune characterization, which can further disclose more cell behavior towards biomaterial.

\section{Conclusion}

Although the results from viability, cytotoxicity, and proliferation among all groups seemed to converge, while exposed to the bovine biomaterial used in this study, SHED decreased their performance. However, when the biomaterial was associated with PRF, a proliferative and stimulatory effect was observed on SHED, indicating that such association can bring an effective benefit in clinical outcomes.

\section{Acknowledgments}

The authors declare no conflict of interests in this study. Also, they would like to thank the synergistic activities displayed by all laboratories and researchers involved in this work.

\section{References}

Abuarqoub, D., Aslam, N., Jafar, H., Abu Harfil, Z., \& Awidi, A. (2020). Biocompatibility of Biodentine ${ }^{\mathrm{TM}}{ }^{\circledR}$ with Periodontal Ligament Stem Cells: In Vitro Study. Dentistry journal, 8(1), 17. https://doi.org/10.3390/dj8010017

Amaral M., B. (2006). Citotoxidade in vitro e biocompatibilidade in vivo de compósitos a base de hidroxiapatita, colágeno e quitosana. 2006. 98p. Dissertação de mestrado. Universidade de São Paulo.

Borenfreund, J., A., \& Puerner- A. (1985). simple quantitative procedure using monolayer cultures for cytotoxicity assays (HTD/NR-90).Journal of tissue culture methods.

Chaim, O., M., Sade, Y., B., da Silveira, R., B., Toma, L., Kalapothakis., E., Chávez-Olórtegui, C., Mangili, O., C., Gremski., W., von Dietrich., C., P., Nader H., B., \& Sanches Veiga S.(2006). Browity. spider dermonecrotic toxin directly induces nephrotoxicity. Toxicol. App. Pharmacol. 15,211(1),64-77.

de Oliveira, L. A., Borges, T. K., Soares, R. O., Buzzi, M., \& Kuckelhaus, S. A. S. Methodological Variations Affect the Release of VEGF in Vitro and Fibrinolysis' Time from Platelet Concentrates. Preprints 2020, 2020030224 (doi: 10.20944/preprints202003.0224.v1).

Dohan Ehrenfest, D. M., Rasmusson, L., \& Albrektsson, T. (2009). Classification of platelet concentrates: from pure platelet-rich plasma (P-PRP) to leucocyte- and platelet-rich fibrin (L-PRF). Trends in biotechnology, 27(3), 158-167. https://doi.org/10.1016/j.tibtech.2008.11.009

Dominici, M., Le Blanc, K., Mueller, I., Slaper-Cortenbach, I., Marini, F., Krause, D., Deans, R., Keating, A., Prockop, D. j., \& Horwitz, E. (2006). Minimal criteria for defining multipotent mesenchymal stromal cells. The International Society for Cellular Therapy position statement. Cytotherapy, 8(4), 315-317. https://doi.org/10.1080/14653240600855905

Fotakis, G., \& Timbrell, J. A. (2006). In vitro cytotoxicity assays: comparison of LDH, neutral red, MTT and protein assay in hepatoma cell lines following exposure to cadmium chloride. Toxicology letters, 160(2), 171-177. https://doi.org/10.1016/j.toxlet.2005.07.001 
Gillies, R., J., Didier., N., \& Denton., M. (1986). Determination of cell number in monolayer cultures. Analytical Biochemistry,Colorado, 1(159).109-113.

He, L., Lin, Y., Hu, X., Zhang, Y., \& Wu, H. (2009). A comparative study of platelet-rich fibrin (PRF) and platelet-rich plasma (PRP) on the effect of proliferation and differentiation of rat osteoblasts in vitro. Oral surgery, oral medicine, oral pathology, oral radiology, and endodontics, 108(5), 707-713. https://doi.org/10.1016/j.tripleo.2009.06.044

Huawei, Q, Hongya, F., Zhenyu, H., \& Yang, S. (2019). Biomaterials for bone tissue engineering scaffolds: a review. RSC Adv., 9, 26252. $10.1039 / \mathrm{c} 9 \mathrm{ra05214c}$

Lendeckel, S., Jödicke, A., Christophis, P., Heidinger, K., Wolff, J., Fraser, J. K., Hedrick, M. H., Berthold, L., \& Howaldt, H. P. (2004). Autologous stem cells (adipose) and fibrin glue used to treat widespread traumatic calvarial defects: case report. Journal of cranio-maxillo-facial surgery: official publication of the European Association for Cranio-Maxillo-Facial Surgery, 32(6), 370-373. https://doi.org/10.1016/j.jcms.2004.06.002

Lisboa, D. G., Fonseca, S. C. da, Stroparo, J. L. de O., Mendes, R. A., Vieira, E. D., Cavalari, V. C., Leão Neto, R. da R., Gabardo , M. C. L. , Deliberador, T. M., Franco, C. R. C., Leão, M. P., \& Zielak, J. C. (2021). Characterization and viability of the stromal vascular fraction from the Bichat fat ball associated with platelets-poor plasma - an option for aesthetic treatments. Research, Society and Development, 10(8), e37010817341. https://doi.org/10.33448/rsd-v10i8.17341

Massuda, C. K. M., Souza, R. V. de, Roman-Torres, C. V. G., Marao, H. F., Sendyk, W. R., \& Pimentel, A. C. (2020). Aesthetic tissue augmentation with an association of synthetic biomaterial and L-PRF. Research, Society and Development, 9(7), e578974502. https://doi.org/10.33448/rsd-v9i7.4502

Miron, R. J., Zucchelli, G., Pikos, M. A., Salama, M., Lee, S., Guillemette, V., Fujioka-Kobayashi, M., Bishara, M., Zhang, Y., Wang, H. L., Chandad, F., Nacopoulos, C., Simonpieri, A., Aalam, A. A., Felice, P., Sammartino, G., Ghanaati, S., Hernandez, M. A., \& Choukroun, J. (2017). Use of platelet-rich fibrin in regenerative dentistry: a systematic review. Clinical oral investigations, 21(6), 1913-1927. https://doi.org/10.1007/s00784-017-2133-Z

Miura, M., Gronthos, S., Zhao, M., Lu, B., Fisher, L. W., Robey, P. G., \& Shi, S. (2003). SHED: stem cells from human exfoliated deciduous teeth. Proceedings of the National Academy of Sciences of the United States of America, 100(10), 5807-5812. https://doi.org/10.1073/pnas.0937635100

Moraschini, V., \& Barboza, E. S. (2015). Effect of autologous platelet concentrates for alveolar socket preservation: a systematic review. International journal of oral and maxillofacial surgery, 44(5), 632-641. https://doi.org/10.1016/j.ijom.2014.12.010

Mosmann T. (1983). Rapid colorimetric assay for cellular growth and survival: application to proliferation and cytotoxicity assays. Journal of immunological methods, 65(1-2), 55-63. https://doi.org/10.1016/0022-1759(83)90303-4

Nakajima, K., Kunimatsu, R., Ando, K., Hiraki, T., Rikitake, K., Tsuka, Y., Abe, T., \& Tanimoto, K. (2019). Success rates in isolating mesenchymal stem cells from permanent and deciduous teeth. Scientific reports, 9(1), 16764. https://doi.org/10.1038/s41598-019-53265-4

Naz, S., Khan, F. R., Zohra, R. R., Lakhundi, S. S., Khan, M. S., Mohammed, N., \& Ahmad, T. (2019). Isolation and culture of dental pulp stem cells from permanent and deciduous teeth. Pakistan journal of medical sciences, 35(4), 997-1002. https://doi.org/10.12669/pjms.35.4.540

Oliveira, N. A. de, Roballo, K. C. S., Lisboa Neto, A. F. S., Sandini, T. M., Santos, A. C. dos, Martins, D. dos S., \& Ambrósio, C. E. (2017). Bioimpressão e produção de mini-órgãos com células tronco. Pesquisa Veterinária Brasileira, 37(9), 1032-1039. 10.1590/s0100-736x2017000900020

Orlic, D., Hill, J. M., \& Arai, A. E. (2002). Stem cells for myocardial regeneration. Circulation research,91(12), 1092-1102. https://doi.org/10.1161/01.res.0000046045.00846.b0

Precheur H. V. (2007). Bone graft materials. Dental clinics of North America, 51(3), 729-viii. https://doi.org/10.1016/j.cden.2007.03.004

Ratnayake, D., \& Currie, P. D. (2017). Stem cell dynamics in muscle regeneration: Insights from live imaging in different animal models. BioEssays : news and reviews in molecular, cellular and developmental biology, 39(6), 10.1002/bies.201700011. https://doi.org/10.1002/bies.201700011

Reilly, T. P., Bellevue, F. H., 3rd, Woster, P. M., \& Svensson, C. K. (1998). Comparison of the in vitro cytotoxicity of hydroxylamine metabolites of sulfamethoxazole and dapsone. Biochemical pharmacology, 55(6), 803-810. https://doi.org/10.1016/s0006-2952(97)00547-9

Rosa, A., L., Shareef, M. Y., \& Noort, R. V. (2000). Efeito das condições de preparação e sinterização sobre a porosidade da hidroxiapatita. Pesqui Odontol Bras., 14:273-7.

Sanada, J. T., Canova, G. C., Cestari, T. M., Taga, E. M., Taga, R., \& Buzalaf, M. A. R. (2003). Análise histológica, radiográfica e do perfil de imunoglobulinas após a implantação de enxerto de osso esponjoso bovino desmineralizado em bloco em músculo de ratos. J Appl Oral Sci., 11:209-15.

Strauer, B. E., Brehm, M., \& Schannwell, C. M. (2008). The therapeutic potential of stem cells in heart disease. Cell proliferation, 41 Suppl 1(Suppl 1), 126145. https://doi.org/10.1111/j.1365-2184.2008.00480.x

Stroparo, J. L. de O., Weiss, S. G., Fonseca, S. C. da, Spisila, L. J., Gonzaga, C. C., Oliveira, G. C. de, Brotto, G. L., Swiech, A. M., Vieira, E. D., Leão Neto, R. da R., Franco, C. R. C., Leão, M. P., Deliberador, T. M., Gabardo, M. C. L., \& Zielak, J. C. (2021). Xenogenic bone grafting biomaterials do not interfere in the viability and proliferation of stem cells from human exfoliated deciduous teeth - an in vitro pilot study. Research, Society and Development, 10(4), e34410414249. https://doi.org/10.33448/rsd-v10i4.14249

Yamada, M. K., \& Watari, F. (2003). Imaging and non-contact profile analysis of Nd:YAG laser-irradiated teeth by scanning electron microscopy and confocal laser scanning microscopy. Dental materials journal, 22(4), 556-568. https://doi.org/10.4012/dmj.22.556 